\begin{tabular}{|lcc|}
\hline & Osmanlı Medeniyeti Araştırmaları Dergisi \\
Journal of Ottoman Civilization Studies & Cilt 6, Sayı 10, Nisan 2020 \& Vol 6, No 10, April 2020 \\
C-ISSN 2458-9519 & C2019 Telif Hakkı OSMED'e aittir & Article Types: Research Article \\
DOI: 10.21021 /osmed.668921 & Makale Türü: Araştırma Makalesi & OSMED, 2020, 6(10): 101 - 114 \\
\hline Geliş Tarihi \& Received: 01.01 .2020 & Kabul Tarihi \& Accepted: 11.04 .2020 &
\end{tabular}

\title{
Osmanlı Devleti’nde İlk Daimi Elçilikler ve Diplomasiye Olan Etkileri
}

\author{
The First Permanent Embassies in the Ottoman Empire and Their Effects on Diplomacy
}

\section{Şuheda GÜNCE*}

$\ddot{O} \mathbf{z}$

Osmanlı Devleti'nin kuruluşundan itibaren yürüttüğü diplomasi, daima tek taraflı ve karşllıksız olmuştur. Bu durum, Osmanlıların siyaseten ve dinen kendilerini diğer devletlerden daha üstün bir noktada görmeleri ile ilgilidir. Ancak on sekizinci yüzyıldan itibaren Batı'da yaşanan gelişmeler, Batının daha ön plana geçmesine imkân tanımış ve Osmanlı Devleti bu gelişmelerden belli bir noktada habersiz kalmıştır. Bu durum, Osmanlı Devleti'nin karşıllıksız/tek taraflı diplomasisinin bir sonucu olarak Batı ile herhangi bir iletişim kanalı kurmaması neticesinde meydana gelmiştir. Dolayısıyla bu sorunu aşma ve sağlıklı bir iletişimi gerçekleştirme ihtiyacı doğmuştur. Bu ihtiyaç, daimi elçiliklerin açılması ile giderilmeye çalışııış̧ır. Daimi elçiliklerin açılması, Osmanlı Devleti’nin kuruluşundan itibaren yürüttüğü karşılıksız diplomasiden, muvazene diplomasisine geçişinin bir başlangıcı olarak görülmüştür. Bu nedenle söz konusu diplomasinin uygun bir şekilde yürütülmesinde daimi elçilikler oldukça önemli bir rol oynamıştır. Bu makalede, Osmanlı Devleti'nde daimi elçiliklerin açılmasının temel sebepleri ve elçiliklerin diplomasiye olan etkilerinin ne boyutta olduğu incelenecektir. Ayrıca elçiler tarafindan ele alınan sefaretnamelerin önemi üzerinde de durulacaktır.

Anahtar Kelimeler: Osmanlılar, diplomasi, elçilik, reformlar, sefaretnameler.

\begin{abstract}
The diplomacy of the Ottoman Empire since its establishment has always been unilateral and non-reciprocity. This is related to the fact that they see themselves politically and religiously superior to other states. However, the developments in the West since the eighteenth century allowed the west to come to the forefront and the Ottoman Empire remained unaware of these developments at a certain level. This was the result of the fact that the Ottoman Empire did not establish any communication channels with the West as a result of its non-reciprocity diplomacy. Therefore, there is a need to overcome this problem and realize a healthy communication. This problem was tried to be solved by opening the permanent embassies. The opening of the permanent embassies has been seen as the beginning of the transition from non-reciprocity diplomacy, which has been carried out since the establishment of the Ottoman Empire, to balance policy. Therefore, the permanent embassies played an important role in the proper functioning of this diplomacy. In this article, the main reasons of the opening of the permanent embassies in the Ottoman Empire and the effects of the embassies on diplomacy will be examined. In addition, the importance of the embassies reports handled by the ambassadors will be emphasized.
\end{abstract}

Keywords: Ottomans, diplomacy, embassy, reforms, embassy reports.

*(Dr.) Milli Eğitim Bakanlığı, mehlika_gnc@hotmail.com; ORCID: orcid.org/0000-0001-9774-3457

Kaynak Gösterme: Günce, Ş. " Osmanlı Devleti'nde Illk Daimi Elçilikler ve Diplomasiye Olan Etkileri". Osmanlı Medeniyeti Araştırmaları Dergisi, 6 (2020): 101 - 114. 


\section{Giriş}

Osmanlı Devleti'nin diğer ülke ve devletlerle olan ilişkileri, kuruluş ve yükseliş dönemlerinden itibaren, doğrudan savaşlar sonucunda gerçekleşmiştir. Askeri açıdan oldukça güçlü olduğundan istediği her şeyi savaşmak suretiyle elde edebilen Osmanlı Devleti, bundan dolayı hem askeri hem de siyasi üstünlüğe sahip olmuştur. Dolayısıyla bu üstünlük diğer devletlerle olan diplomatik ilişkilerde de kendini hissettirmiştir. Osmanlı Devleti tarafından yürütülen diplomatik ilişkilerin en temel özelliği tek taraflı uygulanmasıydı. Bu ilişkilerin tek taraflı olmasının nedenleri arasında savaşlarda elde edilen üstünlük ve gücün yanı sıra Osmanlı Devleti kuruluş felsefesinin de önemli olduğu belirtilmiştir. Zira kimi araştırmacılara göre, Osmanlı Devleti -bir İslam Devleti olarak- fetih politikasının temel hedefi, İslam Dinini mümkün olduğu ölçüde yaymak, Dar ül-Harb'i, Dar ül-Sulh durumuna getirmek ${ }^{1}$ ve bu noktada dış politika etkileşimlerini sürdürmek olmuştur. Dolayısıyla Osmanlı Devleti, diğer Hristiyan devletlere daimi elçiler göndermiyor, sadece kendilerine verilen görevleri yerine getirip dönen, sefaret$i$ mahsusa ile fevkalâde sefirler göndermekle yetiniyordu. ${ }^{2}$ Diğer bazı araştırmacılar ise, Osmanlı Devleti'nin Avrupa'da daimi elçilik açmaması hususunu Dar ül-Harp olayına bağlamanın doğru olmadığını, böyle bir hususun İslam devletler hukuku ile uyuşmadığını ifade ederek, Osmanlı' da uzun süre daimi elçilik açılmamasını 'gelenek'lerle açıklamış daha önceki İslam ve Türk devletlerinde de daimi elçilik uygulamasının bulunmadığına vurgu yapmışlardır. ${ }^{3}$ Dolayısıyla onlara göre bu durumu 'gelenek'le açıklamak daha uygun bir yol olmuştur. Zira Osmanlı Devleti bu süreçte sadece Hristiyan devletlerde değil Müslüman devletlerde de daimi elçilik bulundurmamıştır. Bunların yanı sıra Osmanlı Devleti'nin uluslararası platformda oldukça güçlü bir pozisyonda olması sebebiyle istediklerini kabul ettirebilmesi de, daimi elçilik bulundurma gerekliliğini ortadan kaldırmış, ayrıca dış ülkelerdeki gelişmeleri rapor eden sınır eyaletleri valileri, Kırım Hanları, Eflak ve Boğdan voyvodaları ve ticaret için Avrupa'ya giden tâcirler de yine Babâli'ye bilgi akışını sağlayan kaynaklar arasında bulunduğundan ${ }^{4}$ daimi elçilik bulundurma ihtiyacı hâsıl olmamıştır. Dolayısıyla daimi elçilikler hususunda her ne kadar bu ve bunun gibi farkl1 yorumlar yapılsa da varılan ortak nokta, Osmanl1 Devleti'nin diğer devletleri kendilerine denk görmedikleri ve tek taraflı bir diplomatik ilişki halinde olduklarıdır. Bu bilgiler ışığında şunu söylemek gerekirse, daimi elçilik hususu, Osmanlı Devleti'nin oldukça güçlü olduğu dönemlerinde gündemde olan bir mesele olmadığıdır. Bu süreçte, mütekabiliyet esasına göre mevcut duruma bakıldığında da böyle bir durumun benimsenmediği ve uluslararası arenada tek söz sahibi olarak ön plana çıkan devletin, Osmanlı Devleti olduğu görülmüsştür. Ancak bu husus on sekizinci yüzyıldan itibaren değişmeye başlamış ve tek taraflı diplomasi yerini muvazene diplomasisine bırakmaya başlamıştır. Esasen bu tarihten biraz daha geriye gidildiğinde Osmanlı Devleti'nin genişlemesi ve Avrupa üzerindeki üstünlügünün Karlofça Anlaşması ile durmaya başladığı görülür. Zira bu anlaşmadan sonra, Osmanlı devlet adamları kendileri dışında bir güç ve medeniyetin olduğunu kabul etmek zorunda kalmış ve Avrupa devletleri arasında diplomasi ön plana çıktığından, kendileri de devletlerarası ilişkilerde diplomasiye önem vermeye başlamışlardır. ${ }^{5}$

Diplomasi anlayışını on sekizinci yüzyıla kadar: “ hiçbir Avrupalı Hristiyan devleti eşit haklara haiz muhatap kabul etmemek ve onlarla hiçbir zaman daimi barış içinde olmamak" prensibi üzerine kuran Osmanlı Devleti ${ }^{6}$ bu yüzyılın ikinci yarısından itibaren karşılaştığı çeşitli sorunlar ve Batı' da meydana

\footnotetext{
${ }^{1}$ Ahmet Mumcu, Divan-ı Hümayun (Ankara: Birey ve Toplum Yayınları, 1986), 76.

2 Ahmet Dönmez, "Karşılıklı Diplomasiye Geçiş Sürecinde Osmanlı Daimi Elçiliklerinin Avrupa'da Yeniden Tesisi 1832-1841" (yüksek lisans tezi, Selçuk Üniversitesi, 2006), 8.

3 Türkiye Diyanet Vakfı İslam Ansiklopedisi, Mehmet İpşirli (İstanbul: TDV İslam Araştırmaları Merkezi, 1995), "Elçi” maddesi.

${ }^{4}$ Ali İbrahim Savaş, Osmanlı Diplomasisi, (İstanbul: 3F Yayınevi, 2007), 16.

${ }^{5}$ Selim Hilmi Özkan, Amcazâde Hüseyin Paşa (1644-1702), (Saarbücken: Türkiye Alim Kitapları, 2015$), 82$.

${ }^{6}$ Ali İbrahim Savaş, a.g.e., 13; Namık Sinan Turan, "Osmanlı Diplomasisinde Batı İmgesinin Değişimi ve Elçilerin Etkisi (18. Ve 19. Yüzyıllar)," Trakya Üniversitesi Sosyal Bilimler Dergisi, 6:2 (2004 Haz ), 58.
} 
gelen olayların etkisi altında kalmıştır. Bu süreçte Batı'da meydana gelen yenilik ve gelişmelerden habersiz kalan Osmanlı Devleti, uluslararası diplomaside savaş ve yayılma politikasını bir tarafa bırakarak kendi varlığını muvazene politikası üzerinden sürdürmeyi tercih etmiş ${ }^{7}$ ve bu noktada karşılıklı diplomasiyi sürdürebilmek için, bazı Batılı ülkelerde daimi elçilikler açılması meselesini gündeme getirmiştir. III. Selim döneminde yürütülen bu siyasi yönelim, söz konusu dönemde yapılan birçok yenileşme hareketine de olumlu bir katkı sağlamıştır. İlk daimi elçilik, Osmanlı Devleti'nin eskiden beri resmi olarak iletişim halinde olduğu Fransa'da açılmak istense de Fransız İhtilali'nin oluşturmuş olduğu ortam sebebiyle burada değil de İngiltere' de açılması daha uygun görülmüş ve Yusuf Agâh Efendi gönderilen ilk daimi elçi olarak tarih sahnesinde yerini almıştır.

Batılı ülkelere gönderilen daimi elçiler, ilk aşamada gittikleri ülkelerde bir uyum süreci geçirmişlerdir. Bunun yanı sıra onların maiyetlerindeki genç görevliler ise uzun süre bu ülkelerde kalıp onların lisanlarını öğrenmiş, aynı zamanda Batı kültürünü ve diplomasilerini geniş bir şekilde öğrenerek yetenekli diplomatlar olarak ortaya çıkmışlardır. Bu ülkelerin başta askeri ve siyasi ilişkileri olmak üzere toplumsal ve kültürel değerlerini etraflıca inceleyen daimi elçiler, edindikleri bu bilgileri, daha sonra ülkeye geri dönüşte padişaha arz edecekleri ve resmi bir niteliği olan 'sefaretname' adı verilen belgeler halinde kaleme almışlardır. Kimi elçiler Batı'da gördükleri incelik ve güzellikleri hayranlıkla anlatırken kimisi de maruz kaldıkları olumsuzlukları ifade etmiş ve Batı'yı oldukça sert bir şekilde eleştirmiştir. Söz konusu sefaretnamelerin Osmanlı diplomasisine olan katkıları ilerleyen bölümlerde incelenecektir.

Osmanlı Devleti'nde elçiliklerin faaliyetlerinin neler olduğu ve Osmanlı diplomasisine etkilerinin ne derece olduğuna dair en güvenilir bilgiler, ilk aşamada temel kaynak olarak nitelendirilen ve büyük çoğunluğu bizzat elçiler tarafindan kaleme alınan 'sefaretname ${ }^{8}$ 'lerden elde edilmektedir. Ayrıca elçiler ve sefaretnameler üzerine yapılmış diğer birçok çalışma da bulunmaktadır. Bu konuda en eski çalışma olarak bilinen Hammer'in Osmanlı Imparatorluğu Tarihi adlı eserinin elçilerle ilgili bir listesinde, yine Bursalı Tahir Bey'in Osmanlı Müellifleri adlı eserinin 1924'te basılan üçüncü cildinde, Maurice Herbette'nin Directoire Yönetimi Döneminde Bir Türk Elçisi Moralı Esseyyit Ali Efendi adlı eserinde, Ahmet Refik'in Moralı Esseyyid Ali Efendi'nin Fransa Sefaretnamesi adlı eserinde ${ }^{9}$ ve daha birçok çalışmada elçiler ve sefaretnamelere dair çeşitli bilgiler verilmiştir. Bunların yanı sıra Faik Reşit Unat, Enver Ziya Karal ${ }^{10}$, Karl Teply ${ }^{11}$, Ercüment Kuran ${ }^{12}$, Erhan Afyoncu ${ }^{13}$, Mehmet Alaaddin Yalçınkaya ve Hasan Korkut gibi isimler de yine elçilikler ve sefaretnameler hakkında oldukça geniş çalışmalar ortaya koyan isimlerdir.

Kaleme aldığımız bu çalışmada ise daimi elçiliklerin açılış amacı sorgulanmakta ve Osmanlı diplomasisine olumlu ya da olumsuz yöndeki katkıları incelenmektedir. Aynı zamanda çoğunluğu elçiler tarafindan yazılan sefaretnamelerin süreç içerisindeki katkıları ortaya konmuş ve diplomasiye

\footnotetext{
${ }^{7}$ Ayşe Pul, "Osmanlı-Fransız Diplomasisinin Iki Mühim Evresi: Girit ve Mısır Seferleri," OTAM: Ankara Üniversitesi Osmanlı Tarihi Araştırma ve Uygulama Merkezi Dergisi, 22 (2007), 167.

${ }^{8}$ Kemal Beydilli Osmanlı sefaretnamelerinin kendine özgü bir tür ve kaynak olduğunu belirtmekle beraber, Venedik elçilerinin takrirleri olan 'relazioni'lerle karşılaştırıldığında, siyasi içerik yönünden kaynaklık değerinin düşük olduğunu ifade etmiştir. Kemal Beydilli, "Sefaret ve Sefaretnâme Hakkında Yeni Bir Değerlendirme," Osmanlı Araştırmaları, XXX (2007), 10-11.

${ }^{9}$ Faik Reşit Unat, Osmanlı Sefirleri ve Sefaretnameleri (Ankara: Tarih Kurumu Yayınları, 1968), 1.

${ }^{10}$ Enver Ziya Karal, Halet Efendi'nin Paris Büyükelçiliği (1802-1806) (İstanbul: İstanbul Üniversitesi Yayınları, 1940).

${ }^{11}$ Karl Teply, Dersa'âdet'te Avusturya Sefirleri (Ankara: Kültür Bakanlığı Yayınları, 1988).

${ }^{12}$ Ercüment Kuran, Avrupa'da Osmanlı ikamet Elçiliklerinin Kuruluşu ve Ilk Elçiliklerin Siyasi Faaliyetleri (Ankara: Türk Kültürünü Araştırma Enstitüsü Yayınları, 1988).

${ }^{13}$ Erhan Afyoncu, Tanzimat Öncesi Osmanlı Tarihi Araştırma Rehberi (İstanbul: Yeditepe Yayınevi, 2007).
} 
doğrudan olan etkilerinin tespiti yapılmıştır. Şimdi, Osmanlı Devleti'nin on sekizinci yüzyılının ikinci yarısından sonraki siyasi durumu ve daimi elçiliklerin açılış süreci ele alınacaktır.

1. XVIII. Yüzyıl'ın İkinci Yarısı (1789-1807) Osmanlı Diplomasisine Kısa Bir Bakış ve İlk Daimi Elçiliklerinin Açılması

On sekizinci yüzyıl, hem Osmanlı Devleti'nde hem de dönemin Avrupa'sında oldukça ciddi değişimlerin meydana geldiği bir yüzyıl olarak karşımıza çıkmaktadır. Bilhassa bu yüzyılın ikinci yarısında siyasal, toplumsal, ticari ve sanayi alanında ortaya çıkan yenilikler devletlerin yönetiminde büyük rol oynamıştır. Bir taraftan Batı'daki Fransız reformu hiç şüphesiz bu yüzyıla damgasını vuran bir nitelik arz ederek bütün Avrupa'yı etkisi altına almış tabir-i diğerle ateş çemberiyle sarmışken, diğer taraftan da Osmanlı Devleti'nin içinde bulunduğu Avusturya ve Rusya ile olan savaş durumu da devam etmekteydi.

Osmanlı Devleti'nin devam eden Rusya ve Avusturya Savaşları'nda herhangi bir başarı elde edememesi, Batı'da ortaya çıkan gelişmelerden ve yeniliklerden uzak kalmasına ve bunlara ayak uyduramamasına bağlanmış, bu noktada Osmanlı yönetimi ve askeri düzeni eleştirilmiştir. Dolayısıyla, on sekizinci yüzyıl boyunca Osmanlı Devleti, aralarındaki ittifak ilişkilerinin sürekli değiștiği düşmanlarıyla mücadele etmiş ve artık tek başına mevcut durumunu sürdüremeyeceğini anlamıştır. ${ }^{14} \mathrm{Bu}$ ortamda Osmanlı Devleti, gitgide Batılı siyasi kavramlar ve yöntemlerle olan ilgisini ve yakınlığını arttırmaya çalışmıştır. Şark Meselesi gibi çeşitli kavramların ortaya çıkışı, Osmanlı'nın eskiden beri sürdürmüş olduğu dış siyaset anlayışının değişerek muvazene siyasetinin benimsenmesi, uluslararası platformdaki gelişmeleri takip edebilecek kaynakların yokluğu gibi etkenler, on sekizinci yüzyıldaki diğer gelişmelerle birleşince, III. Selim'in Batılılaşma programının en önemli kısmını oluşturan hususun diplomasi reformu olduğ ${ }^{15}$ anlaşılmaktadır. Her ne kadar III. Selim döneminde yapılan reformların sonraki dönemler için kalıcı bir mirastan mahrum olduğu yorumları yapılsa da, bu dönem islahatlarının asıl katkısı ve mirasının diplomatik alandaki ilişkilerin Batı'ya dönük liberal ve reformist bir entelektüel çekirdeği oluşturduğu ${ }^{16}$ ifade edilmektedir.

Bütün bunlara ek olarak, bu yüzyılın ikinci yarısında devlet ilişkilerini büsbütün başka bir duruma sokan Fransız ihtilalinin çıkması, bütün Avrupa devletlerini önlem amaçlı çeşitli tedbirleri almaya zorlamıştır. ${ }^{17}$ Zira araştırmacılar, "Fransız ihtilali sonucu ortaya çıkan liberalizm, rasyonalizm gibi fikir akımlarının Avrupa'nın içlerine kadar yayılıp çok uluslu imparatorlukları tehdit ederken, Fransa'nın Napolyon'la birlikte kıta Avrupası'nı Fransa'nın liderliğinde birleştirme mücadelesine girdiğini, diğer yandan bu fikir akımlarının kendileri için büyük tehlike olarak gören İngiltere, Rusya, Prusya ve Avusturya gibi devletlerin de Fransa'ya karşı kutsal bir ittifak oluşturduğunu" ${ }^{18}$ ifade etmişlerdir. Dolayısıyla mevcut şartlar, savunma durumuna geçmiş olan Osmanlı Devleti'nin de kendisi için Avrupa'da bir takım müttefikler edinmesini gerektirmiştir. Bunun bir sonucu olarak da yeni dış siyaset stratejisi, diplomasiye ve bunu kullanabilecek diplomatlara olan ihtiyac1 arttırdığ 1 gibi uluslararası gelişmelerin kesintisiz takibini gerektirmiş ve bu durumda da III. Selim'in tek seçeneği, yurt dışına daimi elçiler göndermek olmuştur. ${ }^{19} \mathrm{Bu}$ konu ile ilgili Bernard Lewis, daimi elçiliklerin açılma sebebi olarak Osmanlı'yı Batı devletlerinin normal uygulama sistemine uydurmak ve Avrupa'daki gelişmeler

\footnotetext{
${ }^{14}$ Gül Akyılmaz, "III. Selim'in Dış Politika Anlayışı ve Diplomasi Reformu Çerçevesinde Batılılaşma Siyaseti," Türkler, haz., Hasan Celâl Güzel, Kemal Çiçek, Salim Koca (Ankara: Yeni Türkiye Yayınları, 2002), 1093.

${ }^{15}$ Gül Akyılmaz, a.g.m., 1093.

16 Bülent Tanör, "Anayasal Gelişmelere Toplu Bir Bakış," Tanzimattan Cumhuriyete Türkiye Ansiklopedisi, haz. Murat Belge ve Fahri Aral (İstanbul: Illetişim Yayınları, 1985), 12.

${ }^{17}$ Ahmed Cevdet Paşa, Tarih-i Cevdet (İstanbul: Üç Dal Neşriyat, 1966), 124.

18 Ayşe Pul, a.g.m., 167.

${ }_{19}$ Gül Akyılmaz, a.g.m., 1094; Selim Hilmi Özkan, Osmanlı Devleti ve Diplomasi, (İstanbul: İdeal Kültür Yayıncılık, 2017), 158.
} 
hakkında doğrudan doğruya ve daha güvenilir bilgiler elde etmek istenmesi olarak göstermiştir. ${ }^{20}$ İkamet elçiliklerinin III. Selim devrinden beri kurulması, ilk anda Batılılaşma ve Batı'yı tanımada etkin olmuş, bu dönemde büyük devletlerin arasındaki dengeye dikkat etme, kritik dönemlerde müzakere ve oyalama politikası da Osmanlı diplomasisinin bir tekniği olarak gelişmiştir. ${ }^{21}$ Ancak bu noktada mutlaka değinilmesi gereken oldukça önemli bir husus vardır. Osmanlı Devleti ilk olarak içerisinde bulunduğu zorlu askeri şartları ve mevcut diplomasi durumunu düzeltmek adına çeşitli reformlar yoluna gitmişse de Batı diplomasisi, bu şartlar altındaki Osmanlı'nın zafiyetinden faydalanarak kendi ekonomik ve siyasi üstünlüğünü kabul ettirmiş ve kapitülasyonlar giderek ağırlaşmıştır. ${ }^{22}$ Dolayısıyla Avrupa, kendi ekonomik gücünü Osmanlı'nın içinde bulunmuş olduğu problemli hal üzerine bina etmiş ve hem ekonomik hem de siyasi bir güç olduğunu kabul ettirmiş̧tir.

Daimi elçiliklerin kurulması ile ilgili süreç, Cevdet Tarihi'nde ise şu şekilde ifade edilmiştir: “Avrupa'nın terakkîyât-ı cedîdesi ve Devlet-i Aliyye'nin vakt-ü hâli iktizâsınca düvel-i Avrupa ile peydâ olan revâbıt-ı adîdesi düvel-i Avrupa kâidesince sefâret usûlünün lüzûm-ı vaz'u te'sîsini isbât edib husûsîyle bu evânda râbita-i düveliyyeyi bütün bütün başka bir hâle koyan Fransa ihtilâli zuhûr ile bi'lcümle düvel-i Avrupa'yı tedârükât-ı ihtiyâtiyeye mecbûr ettiğinden Devlet-i Aliyye'nin dahi düvel-i fâhime-i Avrupa nezdinde birer İkâmet Elçisi bulundurmasl derece-i vücûbda görülmekte düvel-i merkûme nezdinde birer elçi gönderilip ve üç sene müddet tekmîlinde anlar celb ve iâde ve yerlerine başkaları irsâl ile minvâl-i meşrûh üzere hem umûr-ı Sefâret idâre ettirilmek ve hem de bu tarîkle ahvâl$i$ düvele vâkıf bâzı zâtler yetiştirilmek üzere "23 sefaret usulüne de bir düzen verilmesinin kararlaştırıldığ 1 görülmektedir. ${ }^{24} \mathrm{Bu}$ hususta eskiden beri Müslümanlarla dost ve barış halinde bulunup Osmanlı Devleti ile hiçbir savaşı olmayan İngiltere'nin İstanbul'da bulunan elçisi ile görüşülüp kararlaştırılarak eski kalyonlar kâtibi Yusuf Agâh Efendi, 1207 (1793) yılı sonunda Londra elçisi olarak, bununla birlikte Mektubî-i Sadr-1 âli halifelerinden Raif Mahmud Efendi onun başkâtibi olarak ve Avrupalıların soylularından sefaretleri maiyetine görevlendirdikleri ateşelere karşı1ık olarak ise Derviş Ağa adında bir maiyetle görevlendirilmişlerdir. ${ }^{25}$ Yusuf Agâh Efendi' nin başkâtibi sıfatıyla İngiltere' de üç yıl kalan Mahmud Efendi, sonraki süreçte Divan-1 Hümayun beğlikçiliğine atanmış, 1800-1805 yılları arasında da reisülküttaplık yapmıştır. ${ }^{26}$

1795 'te elçi tayininde bir adımın daha atılması uygun görülerek Avusturya ve Prusya'ya daimi elçilik açılmasına karar verilmiş, Seyit Ali Efendi Berlin, İbrahim Akif Efendi Viyana elçiliklerine tayin edilmişlerdir. ${ }^{27}$ Ancak Fransa, ilk daimi elçinin kendisi yerine İngiltere'ye gönderilmesini kabullenememiş, böyle bir elçinin Paris'e gönderilmesi ${ }^{28}$ gerektiğini düşünmüştü. Bunun üzerine Fransız Elçisi Verninac'ın, Babıâli nezdindeki yoğun çabaları ve padişahın da uygun görmesiyle Berlin'e tayin edilen Seyyid Ali Efendi'nin Paris'e, Aziz Efendi'nin Berlin'e, İbrahim Akif Efendi'ninse Viyana'ya tayinlerine karar verilmiş, böylelikle ilk denge politikası denemesinde Osmanlı Devleti

\footnotetext{
${ }^{20}$ Bernard Lewis, Modern Türkiye'nin Doğuşu, çev., Metin Kıratlı, (Ankara: Türk Tarih Kurumu Yayınları, 1993), 62.

21 Illber Ortaylı, "Osmanlı Diplomasisi ve Dışişleri Örgütü," Tanzimattan Cumhuriyete Türkiye Ansiklopedisi, haz. Murat Belge ve Fahri Aral (Istanbul: Illetişim Yayınları, 1985), 279.

${ }^{22}$ Mehmet Alaaddin Yalçınkaya, "Kuruluştan Tanzimat'a Osmanlı Diplomasi Tarihi Literatürü," Türkiye Araştırmaları Literatür Dergisi, 1:2 (2003), 437.

${ }^{23}$ Ahmed Cevdet Paşa, Cevdet Tarihi ( Tertib-i Cedit ), haz. Sadık Emre Karakuş-Murat Babuçoğlu, (istanbul: Türkiye Odalar ve Borsalar Birliği Kültür Yayınları,2017), 88-89.; Ahmed Cevdet Paşa, Tarih-i Cevdet (İstanbul: Üç Dal Neşriyat, 1966), 124-125.

${ }^{24}$ Faik Reşit Unat, a.g.e., 17-19.

${ }^{25}$ Tarih-i Cevdet, 125.

${ }^{26}$ Ercüment Kuran, "Türkiye'nin Batılılaşmasında Osmanlı Daimi Elçiliklerinin Rolü," (VI. Türk Tarih Kongresi'nde Sunulan Bildiri, Türk Tarih Kurumu, Ankara, Ekim 20-26, 1961).

27 Gül Akyılmaz, a.g.m., 1095.

${ }^{28}$ Ahmet Dönmez, a.g.t, 25.
} 
Londra, Paris, Berlin, Viyana gibi söz konusu dönemin önde gelen ve izledikleri dış politikalar sebebiyle Osmanlı'yı yakından etkileyen Avrupa başkentlerine daimi temsilcilikler açmıştır. ${ }^{29}$ Böylece bu elçilikler birçok gence belirli bir müddet, bir Avrupa kentinde oturmak, yabancı bir dili öğrenmek ve çağdaş Avrupa ülkeleri arasında ön plana çıkan bazı devrimci fikirleri tanıma firsatı vermiş, bunlardan bazıları dönüşlerinde Babıâli' de memur olmuş orada bürokratik hiyerarşi arasında, kara ve deniz reformlarının subaylar arasında yarattığı gibi, Batı'ya dönük bir azınlık teşkil etmişlerdir. ${ }^{30}$ Ayrıca bu elçilikler Türk toplumuna başlıca üç açıdan yardım etmişlerdir: Batı'yı tanıyan devlet adamları yetişmesine imkân vermişler, Batı'dan asker ve sivil uzmanlar getirilmesine aracı olmuşlar ve Batı'ya gönderilen öğrencilerin işlerini düzenlemişlerdir. ${ }^{31}$

Ancak gönderilmiş olan elçilerin süreç içinde gerçekleştirdikleri diplomatik çalışmalar beklenildiği kadar başarılı olamamıştır. $\mathrm{Bu}$ başarısızlığın nedenleri, seçilen şahısların siyasi tecrübelerinin bulunmamasına ve yabancı dil bilmemeleri sebebiyle birçoğu casus olan Rum tercümanlardan faydalanmalarına bağlanmıştır. ${ }^{32}$ Bunların yanı sıra karşılıklı diplomasinin işlemesi için gerekli bir dışişleri örgütünün olmayışı, merkezle iletişim sorunları, Avrupa devlet adamlarının Osmanlı'nın çıkarlarını önemsememeleri ${ }^{33}$ gibi problemler de yine bu başarısızlıkların nedenleri arasında görülmüştür.

Sonuç olarak 1793 yılında başlatılan daimi elçilikler uygulaması, 1821 yılına gelindiğinde Rum maslahatgüzarlarının Yunan isyanı esnasında kasıtlı bir şekilde yanlış bilgilendirme yapmalarının anlaşılması üzerine II. Mahmut tarafından kaldırılmış ${ }^{34}$ ve yine -belli bir süre- tek taraflı bir diplomasiye geçiş yapılmıştır. Yunan isyanı sebebiyle, yabancı büyükelçilerle teması sağlamakla görevli Divan-1 Hümâyûn tercümanlarının Fenerli Rumlardan seçilmesine son verilip" ${ }^{35}$, 1821'de bir "Babıâli Tercüme Odası" kurulmuş Avrupa dillerinden tercümeler yapacak olan bu müessesede Müslümanlar veya kendilerine güvenilen Ermeniler kullanılmaya başlanmıştır. ${ }^{36}$ İlk aşamada önemsiz olarak görülen bu daire, zaman geçtikçe önem kazanmış, öyle ki bürokrasi içinde siyasi itibar elde edebilmek için başvurulan temel bir mercii haline gelmiştir. Tercüme Odası üyeleri, daimi diplomasi şeklinde gelişen ve diğer Avrupa ülkelerinin devlet sistemiyle mezcolmaya başlayan Osmanlı Devleti’nin en önemli bürokratları arasında yer almışlardır. ${ }^{37}$

\section{Osmanlı Diplomasisinde Elçilerin Rolü}

On sekizinci yüzyılda elçiler, temsil görevlerinin yanı sıra Batı'yı tanıma ve algılamada aracı rol üstlenmişlerdir. ${ }^{38}$ Söz gelimi, bu dönemde Osmanlı'nın Avusturya ile yapılan savaşta başarısız olması ve bunu takip eden süreçte bir antlaşma imzalanmasından sonra III. Selim ilk olarak, örnek alınması düşünülen Avrupa'yı daha iyi tanıyabilmek için Ebubekir Râtıb Efendiyi Viyana'ya göndermiş ve onu,

\footnotetext{
${ }^{29}$ Gül Akyılmaz, a.g.m., 1095.

30 Bernard Lewis, a.g.e., 63.

${ }^{31}$ Ercüment Kuran, Türkiye'nin Batılılaşması ve Milli Meseleler (Ankara: Türkiye Diyanet Vakfı Yayınları, 2013 ), 12.

32 Necdet Aysal, "Çöküşten Mütarekeye Osmanlı'da Haberalma," Ankara Üniversitesi Türk Inkılap Tarihi Enstitüsü Atatürk Yolu Dergisi, 40 (2007 Kas), 528.

33 Ahmet Dönmez, a.g.t., 33.

${ }^{34}$ Ercüment Kuran, Avrupa'da Osmanlı Ikamet Elçiliklerinin Kuruluşu ve Ilk Elçilerin Faaliyetleri 1793-1821 (Ankara: Türk Kültürünü Araştırma Enstitüsü Yayınları, 1988), 64-65.

35 BOA, Hatt-ı Hümayun, No: 1261/48823, 29-12-1238 (1823).

${ }^{36}$ Muhammet Şahin, "Osmanlı Diplomasisinde Değişim ve Osmanlı Devleti’nin Avrupa Devletler Sistemine Girişi," Gazi Üniversitesi Gazi Eğitim Fakültesi Dergisi [Prof. Dr. Reşat Genç Özel Sayı-1] 29/I (2009): 829. Ayrıntılı bilgi için bkz: Bernard Lewis, a.g.e., 87-90.

${ }^{37}$ Ayrıntılı bilgi için bkz. Sezai Balcı, Babıâli Tercüme Odası (İstanbul: Libra Kitap, 2018).

${ }^{38}$ Namık Sinan Turan, a.g.m., 60.
} 
Avusturya'nın bütün kurumlarını görüp tetkik etmek ve bu incelemelerinin sonuçlarını Sultan'a bildirmekle görevlendirmişti. ${ }^{39}$

Daha önce de belirttiğimiz gibi Osmanlı Devleti'nin on sekizinci yüzyıla kadar Batı ile olan diplomatik ilişkileri sürekli bir nitelik arz etmemiştir. Ancak kuruluşundan beri çeşitli siyasi ve ticari meseleleri halletmek için elçiler gönderilmiştir. Bu elçiler kendilerine verilen görevleri yerine getirdikten sonra ise ülkeye geri dönmüşlerdir. Osmanlı elçileri, barış antlaşmaları veya ticari sözleşmeler imzalamak, barış görüşmeleri ya da devletlerarasında arabuluculuk yapmak, herhangi bir antlaşmanın maddelerini görüşmek, çeşitli vergileri almak, Osmanlı Padişahının cülûsunu bildirmek, zafernâme götürmek, Avrupa krallarının tahta çıkış veya taç giyme törenlerinde hazır bulunmak gibi görevlerle yabancı başkentlere gönderilirlerdi. ${ }^{40} \mathrm{Bu}$ elçiler siyasi literatürde "fevkalâde elçi" diye tanımlanmış olup, görevlerini yerine getirdikten sonra hemen ülkelerine geri dönmüşlerdir. ${ }^{41}$ Ancak "ikamet elçisi" olarak isimlendirilen ve gittiği ülkede oturup, ülkesiyle atandığ ülkenin ilişkilerini sürekli olarak yerinde izleyen ve düzenleyen elçilik uygulaması on sekizinci yüzyılın sonuna kadar Osmanlı İmparatorluğu'nda rastlanmayan bir olgu ${ }^{42}$ olarak karşımıza çıkmıştır. Buna karşılık Avrupa devletleri tarafindan İstanbul'da ilk daimi elçilik fethin ertesi yılı Venedik Cumhuriyeti tarafindan kurulmuş, onu 1475 'te Lehistan ${ }^{43}$, 1497'de Rusya, 1525'te Fransa, üç y1l sonra Avusturya, 1583'te İngiltere ve 1612 'de de Hollanda'nın açtığ1 elçilikler takip etmiştir. ${ }^{44}$ "Gâvurdan bir şey ögrenilemeyeceği ve güçsüz kralların sultandan ricalarda bulunmak" amaciyla Babıâli'de temsilcilikler açtığına inanıldığından dolayı, Osmanlı'nın asırlar süren yükselişi ve gerilemesi boyunca Avrupa'da daimi elçilikler açılmamıştı. ${ }^{45}$ Ancak yukarıda da değindiğimiz gibi birçok geçici elçi gönderilmiştir. Osmanlı Devleti, Avrupa'daki gelişmelerden haberdar olmak için ilk kez 1720 yılında Paris'e elçi olarak Yirmisekiz Çelebi Mehmed Efendi'yi gönderirken, ilk ikamet elçiliğini ise 1793 yılında Sultan III. Selim döneminde açmıştır. ${ }^{46}$

Osmanlı Devleti, genellikle eleştirildiği, Avrupa diplomasi anlayışının dışında kalma ve devamlı elçi bulundurma uygulamasına gitmeme siyasetini, güçlü olduğu dönemde kendi menfaati açısından daha uygun görmüş, böylece Avrupa'nın diplomatik oyunlarının ve taahhütlerinin içinde eli kolu bağlı hale düşmemiş, serbest hareket imkânı bulmuş, ayrıca yönetimin başlangıçtan itibaren çeşitli istihbarat kaynaklarına sahip olması da daimi elçilik bulundurmaya bir ölçüde ihtiyaç hissettirmemiştir. ${ }^{47} \mathrm{Bu}$ istihbarî kaynakların yanı sıra, diğer haber alma kaynaklarının başında, Osmanlı hizmetinde bulunan

39 Besim Özcan, "Devleti Yeniden Kalkındırma Hamlesi: Nizam-ı Cedid ve Âkıbeti," islam Tarihi ve Medeniyeti Osmanlılar Siyasi Tarihi-II-, haz. Mehmet Şeker ve Şefaettin Severcan (İstanbul: Siyer Yayınevi, 2018), 112; Özkan, a.g.e., 165.

${ }^{40}$ Muhammet Şahin, a.g.m., 825; Faik Reşit Unat, Osmanlı Sefirleri ve Sefaretnameleri, 17-19.

${ }^{41}$ Maurice Herbette, Fransa'da ilk Daimi Türk Elçisi Moralı Esseyit Ali Efendi [1797-1802], çev., Erol Üyepazarcı (İstanbul: Pera Yayıncılık, 1997), VII.

42 Maurice Herbette, a.g.e,, VII.

${ }^{43}$ Lehistan'ın (Polonya) İstanbul'da ilk daimi elçiliğini 1475 yılında açtığına dair yaygın olarak bilinen bilginin yanlış olduğunu vurgulayan Hacer Topaktaş, bu bilginin Faik Reşit Unat’ın eserinde Bertold Spuler'e atfen verdiği bir bilgiden kaynaklandığını ifade etmiştir. Ancak Spuler'in eserinde söz konusu tarihte Polonya'nın İstanbul'da ilk daimi elçiliğini açtığına dair herhangi bir bilginin bulunmadığını ayrıca Polonya kaynaklarında da böyle bir malumattan bahsedilmediğini vurgulamıştır. Daha ayrıntılı bilgi için bkz: Hacer Topaktaş, “Polonya’nın Türkiye’deki Illk Daimi Elçiliğinin Kurulma Süreci: Tarihsel Dinamikler," Uluslararası iliş̧kiler, 11/43 (2014): 111-115.

${ }^{44}$ Mehmet İpşirli, a.g.m., 8.

${ }^{45}$ Stanford J. Shaw, Eski ve Yeni Arasında Sultan III. Selim Yönetiminde Osmanlı Imparatorluğu, çev., Hür Güldü (İstanbul: Kapı Yayınları, 2008), 249.

${ }^{46}$ Uğur Kurtaran, "Karlofça Antlaşması'ndan Sonra İstanbul’a Gelen Yabancı Elçilerin Ağırlanması ve Yapılan Harcamalar," Tarih Araştırmaları Dergisi, 37/63 (2018), 333.

${ }^{47}$ Mehmet ipşirli, a.g.m., 9. 
muhtelif milletlere mensup mühtediler gelmiş ve kendilerine müteferrikalık, çavuşbaşılık, kapucılık gibi çeşitli görevler verilmiş olan bu kimseler doğrudan veya dolaylı olarak elde ettikleri bilgileri merkeze ulaştırmışlardır. ${ }^{48}$

Osmanlı yönetimi; Hristiyan hükümdarların kendi katlarına daimi elçileri göndermelerini bir saygı işareti olarak algılamış ve bu elçileri çoğu kez küçümsemiş hatta aşağglamıştır. ${ }^{49} \mathrm{Bu}$ tutumun dış ülkelere gönderilen Osmanlı Fevkalâde Elçileri'nde de görüldügünü belirten araştırmacılar konu ile ilgili şu örneği vermişlerdir: “...Örneğin 1669'da Fransa'ya gönderilen Müteferrika Süleyman Ağa, IV. Mehmet'in mektubunu Fransızların Güneş Kral diye yere göğe sığdıramadıkları XIV. Louis'e sunarken; kralın mektubu ayağa kalkarak almasını kabul töreni esnasında alenen istemiş; kral bunu kabul etmeyince hoşnutsuzluğunu açıkça beyan etmiştir. Bu durum XIV. Louis'i çok kızdırmış ama Süleyman Ağa'ya bir şey yapamamış; hıncını Moliére'e Türkleri aşağılayan sahnelerin olacağı bir oyun sipariş ederek çıkarabilmiştir. Bu olayın sonucu olan eser, dilimize Kibarlık Budalası diye çevrilen Boourgeois Gentilhomme oyunudur."50

Ancak, on sekizinci yüzyılın başlarından itibaren bu durum değişmiş Osmanlı Devleti'nin içinde bulunduğu siyasi ve askeri durumdan dolayı İngiltere gibi devletlerin yardımına ihtiyaç duyması artık böyle bir diplomasi anlayışını sürdüremeyeceğini, devletlerarası diplomasi kurallarına uyması gerektiğini göstermişti.

Bunların yanı sıra Osmanlı Devleti'nde bulunan elçilerle iletişimi ve çevirmenlik faaliyetlerini Rumlar yapmaktaydı. Hatta Eflak ve Boğdan beyleri ve Divan-1 Hümayun tercümanları Rum'lardan oluşmaktaydı. $^{51}$ Türkler, yabancı dil öğrenmeyi henüz aşağılık bir iş saydıkları ve yabancı memleketlerde uzun müddet yaşamayı din bakımından uygun görmedikleri için, diplomasi hizmetinde Rumları kullanmayı çok doğal görmüşlerdir. ${ }^{52}$ Ancak bunların devlete olan sadakatleri hususunda bazı problemler bulunmaktaydı. Hatta kimi zaman Osmanlı Devleti'ne ihanet etmişlerdir. Mesela Moralı Seyid Ali Efendi'nin Paris elçiliği sırasında (1797-1802) elçilik tercümanı olan Osmanlı Rum'u Godrika, Fransa adına çalışmış, Babıâli ile Ali Efendi arasında gidip gelen bütün yazıların bir kopyalarını Başbakan Talleyrant'a vermiştir. ${ }^{53}$ Bir diğer örnek ise Fenerli Rum aileleri ile ilgilidir. Fenerli Rumların uygunsuz tavırları ile ilgili III. Selim’in, dönemin kaymakam paşasına yazmış olduğu hatt-1 hümayun şu şekildedir:

"Kaymakam paşa, bu günlerde Fenerli takımı kendi meramlarını terviç için güna-gun eracif ve havadis ve melanetler neşreyledikleri mesmuum oldu. Bunların bu hareketi devletime muzır oluyor. Niçin sen ve sair memurin buna dikkat edip def'ine say etmiyorsunuz? Bu kâfirlere hiç bir şey tesir etmez mi acaba! Hançerlioğlu ibret olmadı mı? Böyle şeyler Eflak ve Boğdan takımından çıkar. Lakin bunlar benim gayret infial edeceğim şeydir. İște bu fesadın defi, suçlu suçsuz bu kâfirlerin ekserini katl ile olur. Bundan sonra bir şey işitmedim, bila-eman cümlesini katlederim. Bunlara sen iyice tenbih eyle, gözlerini açsinlar sonra kendileri bilir."

Görüldüğü üzere bu ve buna benzer birçok olumsuz vaka yaşanmaktaydı. Söz konusu olaylar sonraki süreçlerde de yaşandığı için, II. Mahmut döneminde, bunların üstesinden gelebilmek adına yukarıda bahsetmiş olduğumuz tercüme odaları kurulmuştur. $\mathrm{Bu}$ problemleri aşmaya çalışan Osmanlı yönetiminin, artık Avrupa devletler dengesindeki değişmeleri yakından izlemesi hatta bunlardan

\footnotetext{
48 Mehmet İpşirli, a.g.m., 9.

${ }^{49}$ Ercüment Kuran, a.g.e., 11.

${ }^{50}$ Maurice Herbette, a.g.e., VIII.

${ }^{51}$ Enver Ziya Karal, Osmanlı Tarihi (Ankara: Türk Tarih Kurumu Yayınları, 1983), 9.

52 Enver Ziya Karal, a.g.e., 9.

53 Mehmet İş̧irli, a.g.m., 9.

54 BOA, Hatt-ı Hümayun, No: 239/13375, 29-12-1206 (1792).
} 
yararlanma yollarını araması zorunlu hale gelmiştir. ${ }^{55}$ Dolayısıyla daimi elçiliklerin açılması meselesi bu noktada kurtarıcı bir husus olarak ortaya çıkmıştır.

Osmanlı Devleti'nin Avrupa hakkında bahsetmiş olduğumuz bilgi alma yöntemlerinin yanı sıra, gönderilen elçilerin yazmış oldukları çeşitli sefaretnameler de vardır. Elçiler, askeri, siyasi, iktisadi, sosyal ve kültürel açıdan önemli değişimler yaşayan Avrupa şehirlerini ve ülkelerini birinci elden tanıtan bilgiler vermek için çeşitli sefaretnameler yazmışlardır. Bu eserler, bilhassa Avrupa'ya giden Osmanlı devlet adamlarının, Avrupa'yı nasıl gördükleri, önceliklerinin neler olduğu, Avrupa'nın olumlu ve olumsuz taraflarının neler olduğuna dair önemli bilgileri içeren belgeler olarak karşımıza çıkmıştır.

\section{Elçilerin Kaleme Aldıkları Sefaretnameler ve Özellikleri}

Osmanlı Devleti, kuruluşundan itibaren yabancı ülkelere elçiler göndermiş ve oralardaki siyasi durumlar hakkında çeşitli bilgiler almıştır. On yedinci yüzyıla kadar bu şekilde devam etmiş, ancak bu yüzyılın sonundan itibaren giden elçiler, yola koyuldukları andan itibaren yaşadıklarını ve gördüklerini kaleme almaya başlamışlardır. Elçiler tarafından kaleme alınan bu metinler resmi nitelikte olup, 'sefaretname' olarak adlandırılmıştır. Bu metinlerden edinilen bilgiler oldukça değerli veriler olarak görülmüş̧ür. Nitekim sefaretnameler, Osmanlı Devleti'nin özellikle yabancı devletlerle olan siyasi münasebetlerine göre şekillenen bir iletişim aracı görevini üstlenmiştir. ${ }^{56}$ İletişim aracı olmalarının yanı sıra, söz konusu sefaretnameler çoğunlukla törenler, müzakereler ve diplomatik protokoller, zaman zaman da Avrupa tiyatrosu, modası ve mutfağıyla ilgili çeşitli bilgileri ${ }^{57}$ de konu edinmiştir. Ayrıca insanların yaşam şartları, günlük yaşantıları ve âdetleriyle ilgili verdikleri bilgilerden ötürü de önemli kaynaklar arasında sayılmıştır. ${ }^{58} \mathrm{Bu}$ yönleriyle sefaretnamelerin, seyahatname, hatırat ve siyasi takrir (rapor) özelliklerini bünyesinde barındıran bir tür olduğ $\mathrm{u}^{59}$ yorumları da yapılmıştır.

Sefaretname veya sefaret takrirleri Osmanlı Devletiyle, temasta bulundukları devletlerarasındaki siyasi, ticari ve kültürel ilişkilerin içerik ve kapsamlarını araştırmaya temel teşkil edebilecek yazılı ve basılı kaynakların en elverişli ve değerli olanları arasındadır. ${ }^{60}$ Bilhassa gönderilen ilk elçilerin kaleme aldıkları sefaretnameler daha çok takrir şeklinde olduğundan yalnızca siyasi gelişmeleri yansıttıkları için devletlerarası konuların incelenmesi noktasında önemli raporlar olarak ön plana çıkmışlardır. ${ }^{61} \mathrm{Bu}$ türün bilinen ilk vesikası Nemçe devletine gönderilen Hacı Zağanos'un raporudur ki ${ }^{62}$, Fatih devrinin ilk on yılına denk gelmektedir. ${ }^{63}$ Sonuncusu ise her ne kadar 1872-1877 yılları arasında İran'da elçilik yapan Mehmet Tahir Münif Paşa'nın risalesi olduğu belirtilse de, bu tarihten sonra da sefaretname türünde birçok raporun kaleme alındığı ifade edilmiştir. Zira Mahir Aydın, tamamı II. Abdülhamid döneminde olmak üzere beş ayrı sefaretnamenin kaleme alındığını tespit etmiş ve bunların değerlendirmesini yapmıştır. ${ }^{64}$ Aydın, bu sefaretlerin tam olarak hangi tarihlerde gerçekleştiğini tespit edememekle beraber

\footnotetext{
${ }^{55}$ Maurice Herbette, a.g.e., VIII.

56 Zeynep Karaca, “Osmanlı- Avusturya Sefaretnamelerinin Osmanlı Diplomasisi ve Modernleşme Süreci Üzerine Etkileri," Karamanoğlu Mehmetbey Üniversitesi Edebiyat Fakültesi Dergisi (EFAD), 1:1 (2018 Ara), 26.

57 Stanford J. Shaw, a.g.e., 260.

58 Türkiye Diyanet Vakfı İslam Ansiklopedisi, Kemal Beydilli (İstanbul: TDV İslam Araştırmaları Merkezi, 2009), "Sefaretname" maddesi.

${ }^{59}$ Kemal Beydilli, "Sefaret ve Sefaretnâme Hakkında Yeni Bir Değerlendirme," 10.

${ }^{60}$ Mehmet Alaaddin Yalçınkaya, "Osmanlı Zihniyetindeki Değişimin Göstergesi Olarak Sefaretnamelerin Kaynak Değeri," OTAM: Ankara Üniversitesi Osmanlı Tarihi Araştırma ve Uygulama Merkezi Dergisi, 7 (1996), 325.

${ }^{61}$ Kemal Beydilli, a.g.m., 12.

${ }^{62}$ Ayrıntılı bilgi için bkz. Gümeç Karamuk, “Hacı Zağanos’un Elçilik Raporu,” Belleten LVI / 216 (1992), $391-406$.

63 Mehmet Alaaddin Yalçınkaya, a.g.m, 324-325.

${ }^{64}$ Mahir Aydın, "Livadya Sefâretleri ve Sefâretnameleri," Belgeler XIV / 18 (1989-1992), 312-357.
} 
tespit edebildiği ilk sefaretin 1863 tarihli ve sonuncusunun ise 1914 tarihli olduğunu ve toplamda on bir sefaretten sadece beşine ait sefaretnamenin mevcut olduğunu ifade etmiştir. ${ }^{65}$

Bilindiği üzere on sekizinci yüzyılda Osmanlı-Avrupa arasında yaşanan diplomatik ilişkilerden dolayı elçilik görevleri hızla artmış ve buna paralel olarak da Avrupa'ya ilişkin yazılan sefaretnamelerin sayısında da bir artış olmuştur. ${ }^{66}$ Sefaretnamelerin sayısı hususunda tespit edilebilirlik açısından çeşitli rakamlar ileri sürülmüştür. Zira yapılan arşiv çalışmaları arttıkça bugüne kadar tespit edilemeyen birçok belge ortaya çıkmakta ve sefaretnameler de bu belgeler arasında yer almaktadır. Dolayısıyla sefaretname sayıları dönemden döneme farklılık arz etmektedir. Günümüzde Avrupa, Asya ve Afrika ülkeleriyle ilgili tespit edilen sefaretnamelerin toplam sayıs1 58'dir. ${ }^{67}$ Bunların 46 tanesinin Avrupa hakkında, 12 tanesinin ise Asya ve Afrika hakkında yazıldığı tespit edilmiştir. Yalçınkaya söz konusu sefaretnameleri listeler halinde vermiş ve bilhassa on sekizinci yüzyılın ikinci yarısından itibaren sefaretname yazımının yoğunlaştığını belirtmiştir.

Bunların yanı sıra Avrupa hakkında yazılan bazı sefaretnamelere bakıldığında onların kaynaklarını kullanarak ve yabancı dilde yazıldıklarını da görmekteyiz. Söz konusu eserlerin ilki Mahmud Raif Efendi'nin İngiltere'yi anlatan ve o zamana kadar alışılmışın dışında bir tarz ve usulde Türkçe dışında Fransızca (Batı dilinde) yazmış olduğu sefaretnamedir ki onun yazmış olduğu bu sefaretname tartışılamayacak derecede nesneldir. ${ }^{68}$ Daimi elçilikler açılmadan hemen önce ve açıldığı dönemlerde Avrupa kentleri hakkında kaleme alınan çeşitli sefaretnameleri şu şekilde sıralayabiliriz:

- Ebûbekir Râtib Efendi, Nemçe Sefaretnâmesi ve Lâyihası, 1791-1792

- Mustafa Rasih Paşa, Rusya Sefaretnâmesi, 1793-1794

- Yusuf Âgâh Efendi, Havâdisnâme-i Ingiltere, 1793-1797

- Mahmud Raîf Efendi, Journal du Voyage de Mahmoud Raif Efendi Engleterre-écrit Par LuyMéme, 1793-1797

- Giritli Ali Aziz Efendi, Prusya Sefaretnâmesi, 1797-1798

- Moralı Seyyid Ali Efendi, Fransa Sefaretnâmesi, 1797-1802

- Mehmed Saîd Gâlib Efendi, Fransa Sefaretnâmesi, 1802

- Seyyid Mehmed Emîn Vâhid Efendi, Fransa Sefaretnâmesi, 1806

Sefaretnameler, ele aldığı konular itibariyle çeşitli sınıflandırmalara tabi tutulmuşlardır. Kimisi içerikleri açısından seyahat günlüğü veya hatırat şeklinde iki ana gruba ayırırken kimisi de özel, genel ve her iki özelliği de taşıyan sefaretnameler şeklinde üç gruba ayırmıştır. Özel sefaretnameler olarak değerlendirilenler, elçilikle görevli olanların gerçek memuriyetlerinin ne suretle yapıldığına ait raporlardır ki bunlar, görevin nasıl yapıldığı ve sonucunun ne olduğu kaydedilenlerdir ve çoğunlukla siyasi bilgileri ihtiva eden türler ${ }^{69}$ arasında yer almaktadırlar. Özel sefaretnamelere en belirgin örnekler olarak 1787 yılında Fas Sultanına gönderilen Ahmed Azmi Efendi'nin Fas Sefaret Takriri ${ }^{70}$, Seyyid Mehmed Refi'i Efendi'nin Iran Sefaretnamesi ve Mehmed Namık Paşa'nın Takrirleri gösterilebilir. ${ }^{71}$ Genel özellikli sefaretnameler ise, elçilerin gezip gördükleri yerlerin idari, sosyal ve ekonomik hayat1, askeri durumu, kültürü, sanatı, eğitim siyaseti, endüstrisi, medeniyet seviyesi hakkında edindikleri fikir

\footnotetext{
65 Mahir Aydın, a.g.e., 323.

${ }^{66}$ Hasan Korkut, Osmanlı Elçileri Gözü Ile Avrupa (İstanbul: Gökkubbe Yayınları, 2007), 19.

67 Mehmet Alaaddin Yalçınkaya vd., Osmanlı Diplomasi Tarihi: Kurumları ve Tatbiki, (Ankara: Altınordu Yayınları, 2018), 28.

${ }^{68}$ Mehmet Alaaddin Yalçınkaya, “Osmanlı Zihniyetindeki Değişimin Göstergesi Olarak Sefaretnamelerin Kaynak Değeri," 322-323.

${ }^{69}$ Mehmet Alaaddin Yalçınkaya, a.g.m., 325.

70 Hasan Korkut, a.g.e., 20.

${ }^{71}$ Mehmet Alaaddin Yalçınkaya, a.g.m., 325.
} 
ve gözlemleri içerir. ${ }^{72}$ Bu hususta verilmiş en iyi örnek Yirmisekiz Çelebi Mehmed Efendi'nin Fransa Sefaretnamesi' dir. Tiyatro, opera, rasathane ve hastahanelerden; askeriyeden, hayvanat bahçesinden; konaklar ve saraylardan övgü ile bahseden Yirmisekiz Çelebi Mehmed Efendi'nin bu eseri, sonraları Lâle Devri diye adlandırılacak döneme zemin hazırlaması bakımından önemlidir. ${ }^{73}$ Her iki özelliği de taşıan sefaretnamelere ise Ebubekir Râtib Efendi'nin Nemçe Sefaretnamesi örnek olarak gösterilmiş ve Râtib Efendi'nin Viyana' da hem toplumsal ve kültürel alanla ilgili gözlemlerini hem de burada görme firsatı bulduğu kurumlar hakkındaki bilgileri sefaretnamesinde güzel bir üslupla anlattığ ${ }^{74}$ ifade edilmiştir.

Sefaretname içeriklerinin oldukça çeşitlilik arz ettiği ve onlarda verilen bilgilerin değerinin tamamen söz konusu sefirin entelektüel ilgi ve eğitim düzeyi ile bilgiye açıklık derecesine bağlı olduğu iddia edilmiş, sefirlerin Osmanlı bürokrasisindeki görev alanları ( askeriye, ilmiye, kalemiye ), entelektüel ilgileri, elçi olarak görev yaptıkları süre zarfı ve gittikleri ülkelerin, sefaretnamelerde öne çıkardıkları konularda farklılıklar oluşturduğu ${ }^{75}$ ifade edilmiştir. Sefirlerin gözlemlerini etkileyecek bir diğer hususun ise; sefirlerin görev yaptıkları dönemde Osmanlı Devleti ile elçilik göreviyle gidilen ülke arasındaki tarihi, siyasi, iktisadi ve sosyo-kültürel ilişkilerin sefirlerin görüşlerini etkilediği yönündedir ki on sekizinci yüzyılın başındaki Osmanlı-Fransa arasındaki ittifaka dayalı iyi ilişkilerin, bazı sefirlerin (Çelebi Mehmed Efendi gibi) gözlemlerinde etkili olduğ ${ }^{76}$ ifade edilmiştir.

Sefaretnamelerin her ne kadar içerik açısından çeşitlilik arz etse de, özellikle siyasi ağırlıklı olanlarının diplomasiye doğrudan etkisi olduğu bilinen bir husus olarak karşımıza çıkmaktadır. Bu noktada bilhassa III. Selim döneminde yurtdışına gönderilen kimi elçilerin geri döndüklerinde Sultan'a sundukları layiha tarzındaki raporlar, özellikle o dönemde oldukça yoğun bir şekilde başlayan modernleşme çalışmalarına yön verecek nitelikte ciddi katkıları olmuştur. Örneğin askeri alanda görüşler içeren ve Avrupa'nın uygulamalarını ihtiva eden bazı raporların Nizâm-ı Cedit gibi önemli uygulamalara temel teşkil ettiği kaynaklarımız tarafından ele alınmıştır.

Kısaca şunu ifade etmek gerekir ki Osmanlı Devleti, Batılı ülkeleri tanımak ve oradaki gelişmeleri takip edebilmek adına göndermiş olduğu elçiler aracılığıyla kaleme alınan bu vesikalardan; Batılıların askeri, siyasi ve kültürel durumlarının nasıl olduğunu belli bir ölçüye kadar öğrenmek istemiştir. Bunun sonucunda kendilerinin yenileşme ve gelişme hususundaki ihtiyaçlarının neler olduğunu tespit etmeye çalışmış bu noktada elçiler aracılığıyla gelen söz konusu vesikalardan oldukça fazla istifade etmiştir. Bu belgelerde yer alan durumları kendi yaşam koşullarına belirli bir çerçevede uygun hale getirmiş ve dönemin içinde bulunduğu problemleri bu yolla halletmeye çalışmıştır. Daha önce de belirttiğimiz gibi sefaretnameler yenileşme yolunda, Batı'ya açılma yolunda ve karşılıklı iletişim kurma hususunda oldukça önemli bir başvuru kaynağı haline gelmiş, bu açıdan islahat fikirlerine zemin oluşturan bir nitelik arz etmiştir.

\section{Sonuç}

Osmanlı Devleti'nin, klasik dönemde içinde bulunduğu siyasi ve askeri güç sayesinde Batılı devletlerle iletişimi karşılıksız diplomasiye dayanmaktaydı. Bilindiği gibi Osmanlı Devleti kuruluşundan itibaren kendisinden daha güçsüz olarak gördüğü devletlerde sürekli olarak temsil edilmeyi küçüklük olarak gördüğünden sadece geçici surette diğer devletlere elçiler göndermiş ve bu elçiler verilen görevleri yerine getirdikten sonra geri dönmüşlerdir. Ad hoc diplomasi denen bu

\footnotetext{
72 Hasan Korkut, a.g.e., 21.

${ }^{73}$ Hasan Korkut, a.g.e., 21.

${ }^{74}$ Hasan Korkut, a.g.e., 21. Ayrıntılı bilgi için bkz: Faik Reşit Unat, s. 43-46.

75 Hasan Korkut, "Osmanlı Sefaretnameleri Hakkında Yapılan Araştırmalar," Türkiye Araştırmaları Literatür Dergisi, $1: 2$ (2003 Eyl), 494.

${ }^{76}$ Hasan Korkut, a.g.m., 495.
} 
diplomasi yöntemi geçici bir nitelik arz etmiş ve bunun temel nedeni ise Osmanlı Devleti'nin bu durumu kendi üstünlügünün bir nişanesi olarak görmüş olmasıydı. Bunun dişında tek taraflı olan bu diplomasi anlayışının daha önce de değindiğimiz gibi dini ve kültürel birçok sebebi bulunmaktaydı. Ancak bu politika, zaman içerisinde Batı'da meydana gelen yenilikler ve Osmanlının bilhassa savaşlardaki askeri başarısızlıkları sonucunda Osmanlıya zarar veren bir husus haline gelmiştir.

Nitekim Osmanlı Devleti'nin çeşitli başarısızlıklar karşısında kendisi için bazı müttefikler bulması ve yine Batı' da meydana gelen yeniliklerden haberdar olarak kendini geliştirmesi, bir zorunluluk haline gelmişti. Askeri açıdan böyle kötü bir dönem geçiren Osmanlı'nın esasında tek çıkış noktası, çağın gerektirdiği diplomatik yollara başvurması olmuştur. On sekizinci yüzyıla kadar karş1lıksız diplomasi anlayışıyla varlığını sürdüren Osmanlı Devleti, bu yüzyıldan itibaren söz konusu anlayışın değiştirilmesi gerektiğini anlamış ve bir diplomasi reformuna gidilmesinin gerekli olduğunu görmüştür. Bu noktada karş11ıklı diplomasiye geçiş sürecinde atılan ilk adım, Batılı devletlerde daimi elçilikler açmak olmuştur. Bu elçiliklerin açılış amacı olan, daha doğru ve daha güvenilir bilgilerin ilk elden alınması hususu, söz konusu diplomatik süreçte hayati önem taşıyan bir nokta olarak ortaya çıkmıştır. III. Selim döneminde ikamet elçilikleri konusundaki çalışmalar başlatılmış ve muvazene diplomasisi resmen uygulamaya konulmuştur. $\mathrm{Bu}$ uygulama neticesinde ilk elçiler Avrupa'ya gönderilmiş ve gerekli devlet işleri karşlıklı olarak sürdürülmeye başlanmıştır. Böylece Osmanlı Devleti yüzyıllar boyunca sürdürmüş olduğu ad hoc diplomasisinden vazgeçerek, yenidünyaya yön veren muvazene diplomasisine geçiş yapmıştır. Çalışmamızda ele aldığımız bu husus, Osmanlı diplomasisi açısından lehte sonuçlar ortaya çıkarmıştır. Ancak kısa bir süre sonra bu elçiliklerden gereken ölçüde fayda sağlanamadığı görülmüş ve özellikle harcamalar noktasında karşılaşılan zorluklar daimi elçiliklerin gerekli olup olmadığı noktasında bazı tartışmalara sebebiyet vermiştir. Ve 1821 yılına gelindiğinde ise III. Selim tarafından kurulmuş olan ikamet elçilikleri kapatılmıştır.

Avrupa ülkelerine gönderilen elçilerin, buradaki devletlerin durumlarını anlatmak için ele aldıkları sefaretname adı verilen raporlara gelindiğinde ise, bunların Osmanlı diplomasi tarihi açısından oldukça önemli ve ana kaynak niteliği taşıyan belgeler olduğu bilinmektedir. Bu vesikalar, elçilerin bulundukları şehirleri o dönemin şartlarında her ne kadar bütün yönleriyle izah edemese de en azından Batılı ülkeler hakkında çeşitli bilgiler (özellikle askeri ve ticari bilgiler) vererek genel bir tablonun oluşmasına zemin hazırlamıştır. Söz konusu dönemde sefaretnamelerin verdiği bilgiler ışı̆̆ında, reformlara dair nasıl adımlar atılması gerektiği hususu daha ayrıntılı bir şekilde ele alınabilmiştir. En nihayetinde şunu söylemek gerekir ki, bu belgelerin Osmanlı modernleşmesi ve Batılılaşma süreci üzerindeki etkisi ve buna ortam hazırlaması reddedilemeyecek bir gerçek olarak karşımızda durmaktadır.

\section{Kaynakça}

\section{Arşiv Belgeleri}

BOA, Hatt-1 Hümayun, 239/13375, H-29-12-1206.

BOA, Hatt-1 Hümayun, 1261/48823, H-29-12-1238.

\section{Telif Eserler}

Afyoncu, Erhan. Tanzimat Öncesi Osmanlı Tarihi Araştırma Rehberi. İstanbul: Yeditepe Yayınevi, 2007.

Akyılmaz, Gül. “III. Selim'in Dış Politika Anlayışı ve Diplomasi Reformu Çerçevesinde Batılılaşma Siyaseti." Türkler, Hasan Celâl Güzel, Kemal Çiçek ve Salim Koca. Ankara: Yeni Türkiye Yayınları, 2002.

Aydın, Mahir. “Livadya Sefâretleri ve Sefâretnameleri.” Belgeler XIV / 18 (1989-1992), 312-357. 
Aysal, Necdet. "Çöküşten Mütarekeye Osmanlı'da Haberalma." Ankara Üniversitesi Türk İnkılap Tarihi Enstitüsü Atatürk Yolu Dergisi. 40 (2007 Kas), 523-543.

Balcı, Sezai. Babıâli Tercüme Odası. İstanbul: Libra Kitap, 2018.

Beydilli, Kemal. "Sefaret ve Sefaretnâme Hakkında Yeni Bir Değerlendirme." Osmanlı Araştırmaları, XXX (2007), 9-30.

Dönmez, Ahmet. "Karşılıklı Diplomasiye Geçiş Sürecinde Osmanlı Daimi Elçiliklerinin Avrupa'da Yeniden Tesisi 1832-1841.” Yüksek lisans tezi, Selçuk Üniversitesi, 2006.

Herbette, Maurice. Fransa'da İlk Daimi Türk Elçisi Moralı Esseyit Ali Efendi [1797-1802]. Çev., Erol Üyepazarc1. İstanbul: Pera Yayınc1l1k, 1997.

Karaca, Zeynep. "Osmanl1- Avusturya Sefaretnamelerinin Osmanlı Diplomasisi ve Modernleşme Süreci Üzerine Etkileri.” Karamanoğlu Mehmetbey Üniversitesi Edebiyat Fakültesi Dergisi (EFAD). 1:1 (2018 Ara), 9-32.

Karal, Enver Ziya. Halet Efendi'nin Paris Büyükelçiliği (1802-1806). İstanbul: İstanbul Üniversitesi Yayınlar1, 1940.

Karal, Enver Ziya. Osmanlı Tarihi. Ankara: Türk Tarih Kurumu Yayınları, 1983.

Karamuk, Gümeç. “Hacı Zağanos’un Elçilik Raporu.” Belleten LVI / 216 (1992), 391-406.

Korkut, Hasan. "Osmanlı Sefaretnameleri Hakkında Yapılan Araştırmalar." Türkiye Araştırmaları Literatür Dergisi. 1:2 (2003 Eyl), 491-512.

Korkut, Hasan. Osmanlı Elçileri Gözü İle Avrupa. İstanbul: Gökkubbe Yayınları, 2007.

Kuran, Ercüment. “Türkiye'nin Batılılaşmasında Osmanlı Daimi Elçiliklerinin Rolü.” VI. Türk Tarih Kongresi'nde Sunulan Bildiri, Türk Tarih Kurumu, Ankara, Ekim 20-26, 1961.

Kuran, Ercüment. Avrupa'da Osmanlı İkamet Elçiliklerinin Kuruluşu ve İlk Elçilerin Faaliyetleri 17931821. Ankara: Türk Kültürünü Araştırma Enstitüsü Yayınları, 1988.

Kuran, Ercüment. Türkiye'nin Batılılaşması ve Milli Meseleler. Ankara: Türkiye Diyanet Vakfı Yayınlar1, 2013.

Kurtaran, Uğur. “Karlofça Antlaşması'ndan Sonra İstanbul'a Gelen Yabancı Elçilerin Ağırlanması ve Yapılan Harcamalar.” Tarih Araştırmaları Dergisi, $37 / 63$ (2018), 331-370.

Lewis, Bernard. Modern Türkiye'nin Doğuşu. Çev., Metin Kıratlı. Ankara: Türk Tarih Kurumu Yayınlar1, 1993.

Mumcu, Ahmet. Divan-ı Hümayun. Ankara: Birey ve Toplum Yayınları, 1986.

Ortayl1, İlber. "Osmanlı Diplomasisi ve Dişişleri Örgütü.” Tanzimattan Cumhuriyete Türkiye Ansiklopedisi, Murat Belge ve Fahri Aral. İstanbul: İletişim Yayınları, 1985.

Özcan, Besim. "Devleti Yeniden Kalkındırma Hamlesi: Nizam-1 Cedid ve Âkıbeti." İslam Tarihi ve Medeniyeti Osmanlılar Siyasi Tarihi-II-, Mehmet Şeker ve Şefaettin Severcan. İstanbul: Siyer Yayınevi, 2018.

Özkan, Selim Hilmi. Amcazâde Hüseyin Paşa (1644-1702). Saarbücken: Türkiye Alim Kitapları, 2015.

Özkan, Selim Hilmi. Osmanlı Devleti ve Diplomasi, İstanbul: İdeal Kültür Yayınc1lık, 2017.

Paşa, Ahmed Cevdet. Cevdet Tarihi ( Tertib-i Cedit ). Sadık Emre Karakuş ve Murat Babuçoğlu. İstanbul: Türkiye Odalar ve Borsalar Birliği Kültür Yayınları, 2017. 
Paşa, Ahmed Cevdet. Tarih-i Cevdet. İstanbul: Üç Dal Neşriyat, 1966.

Pul, Ayșe. "Osmanl1-Fransız Diplomasisinin İki Mühim Evresi: Girit ve Mısır Seferleri." OTAM: Ankara Üniversitesi Osmanlı Tarihi Araştırma ve Uygulama Merkezi Dergisi. 22 (2007), 159-176.

Savaş, Ali İbrahim. Osmanlı Diplomasisi. İstanbul: 3F Yayınevi, 2007.

Shaw, Stanford J. Eski ve Yeni Arasında Sultan III. Selim Yönetiminde Osmanlı İmparatorluğu. Çev., Hür Güldü. İstanbul: Kap1 Yayınları, 2008.

Şahin, Muhammet. "Osmanlı Diplomasisinde Değişim ve Osmanlı Devleti'nin Avrupa Devletler Sistemine Girişi.” Gazi Üniversitesi Gazi Eğitim Fakültesi Dergisi [Prof. Dr. Reşat Genç Özel Sayl1] 29/I (2009): 824-834.

Tanör, Bülent. “Anayasal Gelişmelere Toplu Bir Bakış.” Tanzimattan Cumhuriyete Türkiye Ansiklopedisi, Murat Belge ve Fahri Aral. İstanbul: İletişim Yayınları, 1985.

Teply, Karl. Dersa 'âdet'te Avusturya Sefirleri. Ankara: Kültür Bakanlığı Yayınları, 1988.

Topaktaş, Hacer. "Polonya'nın Türkiye'deki İlk Daimi Elçiliğinin Kurulma Süreci: Tarihsel Dinamikler." Uluslararası İlişkiler, 11/43 (2014): 105-125.

Turan, Namık Sinan. “Osmanlı Diplomasisinde Batı İmgesinin Değişimi ve Elçilerin Etkisi (18. Ve 19. Yüzyıllar).” Trakya Üniversitesi Sosyal Bilimler Dergisi. 6:2 (2004 Haz), 57-86.

Türkiye Diyanet Vakfı İslam Ansiklopedisi. Kemal Beydilli. 36. cilt. İstanbul: TDV İslam Araştırmaları Merkezi, 2009.

Türkiye Diyanet Vakfı İslam Ansiklopedisi. Mehmet İpşirli. 11. cilt İstanbul: TDV İslam Araştırmaları Merkezi, 1995.

Unat, Faik Reşit. Osmanlı Sefirleri ve Sefaretnameleri. Ankara: Tarih Kurumu Yayınları, 1968.

Yalçınkaya, Mehmet Alaaddin, Sezai Balcı, Musa Kılıç, Uğur Kurtaran, Ahmet Dönmez, Turgut Subaşı ve Necmettin Alkan. Osmanlı Diplomasi Tarihi: Kurumlarl ve Tatbiki, (Ankara: Altınordu Yayınları, 2018), 28.

Yalçınkaya, Mehmet Alaaddin. “Kuruluştan Tanzimat'a Osmanlı Diplomasi Tarihi Literatürü.” Türkiye Araştırmaları Literatür Dergisi. 1:2 (2003), 423-489.

Yalçınkaya, Mehmet Alaaddin. "Osmanlı Zihniyetindeki Değişimin Göstergesi Olarak Sefaretnamelerin Kaynak Değeri." OTAM: Ankara Üniversitesi Osmanlı Tarihi Araştırma ve Uygulama Merkezi Dergisi. 7 (1996), 319-338. 